\title{
Physical Model Test Study of the Relationship Between Loess Landslide and Rainfall
}

\author{
Jiaming $\operatorname{Han}^{*}$
}

School of Architecture and Civil Engineering, Xi'an University of Science and Technology, Xi'an, Shannxi, 710054, China

\begin{abstract}
Launching research has important theoretical and practical value on model test study of the relationship between loess landslide and rainfall. According to the monitoring data of model test of loess slope, formula expression of safety factor has been fitted on landslide. Firstly, the loess slope damage process was monitored at different rainfall intensity, rainfall duration through rainfall landslide model tests. Secondly, some parameters were determined by laboratory tests, such as loess unit weight, moisture content, shear strength. Thirdly, the relational expression was fitted between moisture and rainfall intensity, rainfall duration, cohesion, internal friction angle, unit weight. Finally, moisture content being an intermediate variable, the expression was got between landslide safety factor and rainfall intensity, rainfall duration.
\end{abstract}

Keywords: Model test, landslide, loess, rainfall infiltration, safety coefficient.

\section{INTRODUCTION}

Researching mechanism of rainfall-induced loess landslides has important engineering significance. Test is a effective method for solving this complex problem Currently, there are many experts and scholars have done a lot of exploration and research on the relationship between loess landslide and rainfall.

In the aspect of rainfall infiltration, WANG Hui-fang et al. investigated on rainfall infiltration and solute transport in layered porous and fractured media [1]. Marcus Schindewolf et al. created the erosion 2D/3D soil erosion model and researched model parameterization by using a small-scale rainfall simulator and upstream runoff simulation [2]. Ravindra V. Kale et al. established Green-Ampt infiltration models for varied field conditions [3]. Veena U Joshi et al. estimated infiltration rate, run-off and sediment yield under simulated rainfall experiments [4]. X.B. Tu et al. monitored rainfall infiltration in a loess slope and analysised of failure mechanism of rainfall-induced landslides in field [5]. H. Kato et al. measured infiltration rate using an oscillating nozzle rainfall simulator in the cold, semiarid grassland of Mongolia [6]. LI Jie et al. physically simulated urban rainfall infiltration [7]. $\mathrm{H}$. Meng et al. developed and tested a terrain-based hydrologic model for spatial hortonian infiltration and runoff/on [8]. Min Lee et al. performed two instrumented laboratory models for the study of rainfall infiltration into unsaturated soils [9].

In the aspect of slope stability analysis, Zonghu Liao et al. prototyped an experimental early warning system for rainfall-induced landslides in Indonesia using satellite remote sensing and geospatial datasets [10]. Aurelian $\mathrm{C}$ et al. monitored and simulated variations in matric suction during rainfall in a residual soil slope [11]. Zhaocai Zhang et al. analysed effects of rain infiltration on fissured slope stability [12]. Jiang Zhong-Ming et al. researched seepage characteristics of thick coating slope in raining condition [13]. Suzuki et al. did work of groundwater flow after heavy rain in landslide-slope area from 2-D inversion of resistivity monitoring data [14]. Gu Cheng-Zhuang et al. analysed flow motion and its effect on the slope stability of plane sliding landslide saturated under heavy-rain by a case [15]. Wang Jin-Long et al. analysed of infiltration of atomized rain into plunge pool slope in Wudongde hydropower project with numerical method [16].

Although they have obtained a large number of achievements from different aspects of rainfall and landslide disaster, complexity of the actual situation cause that the research result are generally difficult to accurately reflect the real situation in the landslide body. So mechanism of rainfallinduced loess landslides should be researched through test method.

\section{PHYSICAL TEST MODEL}

Physical model tests of loess slope uses similar theory under rainfall infiltration. Studying the failure formation mechanism is through reduced-size Physical model of loess slope. Model test is generally required to meet geometric similarity, kinematic similarity, dynamics similarity and physics similarity.

In order to be able to better analyse of the loess landslide mechanism under rainfall infiltration, the physical model of the loess slope has established under artificial rainfall that geometric kinematics, dynamics, physics similarity ratio are 1. Outdoor area can provide sufficient space for the model test. The test of water, power, facilities are good that can 
satisfy the requirement of the test instruments and used water very well.

Separating and removing the debris among loess, the loess can be repeated use of the test. The loess was spreaded out in the sun exposure in order to make the initial water content of materials more uniform. Because the test to simulate slope stability state of different rainfall intensity, duration, large amount of earthwork was required. So the filling loess need to repeat use. In order to meet the homogeneity of the sample and get more reliable test results, same slope test step was adopted.

The loess slope high was $0.7 \mathrm{~m}$, slope angle $90^{\circ}$ (Fig. 1). Slope is stratified filling. The thickness of each layer is $20 \mathrm{~cm}$.

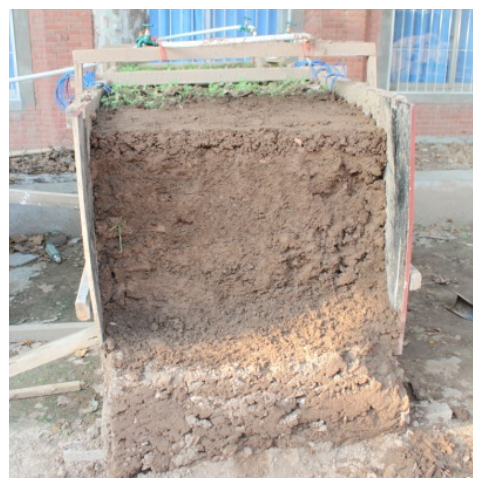

Fig. (1). Model Test of Loess Slope.

Because the sliding surface does not necessarily go through the toe, a rectangular dimensions of $0.3 \mathrm{~m} \times 1.0 \mathrm{~m} \times$ $0.7 \mathrm{~m}$ of clods was hollowed out to simulate this condition (Fig. 2).

Rainfall system mainly include the tap and water supply pipeline, by adjusting the water supply and water supply time to simulate rainfall intensity and rainfall duration. Firstly, the PVC pipe is used to connecte four taps that is distributed on the top of the slope model. In order to simulate the rain completely uniform infiltrating, a plane of $1300 \mathrm{~mm}$ long, $600 \mathrm{~mm}$ wide, deep soil bin of $20 \mathrm{~mm}$ is opened in the top center to prevent rain vertical erosion data from uneven and deviation. The effective area of rainfall system is 0.78 square meters.

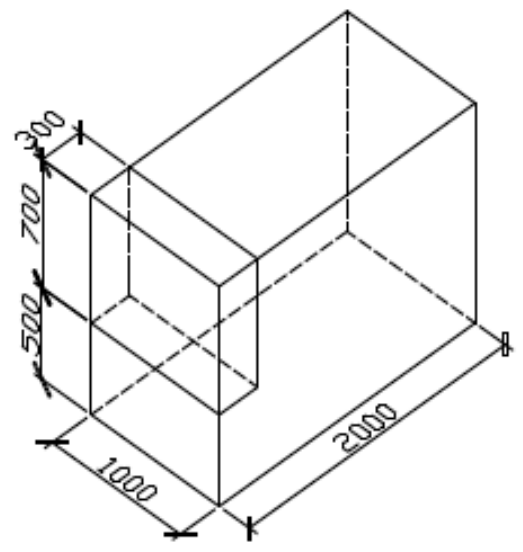

Fig. (2). Model Dimensions.
Test of materials and measurement instruments mainly include: the reinforcement board; Trials connecting the faucet is PVC pipe, about the length of ten meters; Experiment uses the ordinary water tap to simulate rainfall and records flow to simulate rainfall; Test distance is measured by rotor meter; Test of loess samples are gotten by stainless steel cutting ring knife for the determination of soil physical parameters; Experiments use electronic balance to weigh objects quality for in the determination of index in three-phase soil; Test used in the measuring cylinder capacity of $50 \mathrm{ml}$; Steel tape is used to measure the height of sampling test and plans to take samples at $40 \mathrm{~cm}, 80 \mathrm{~cm}$ depth; Test of shear strength parameters included soil, namely, cohesion and internal friction angle, is obtained by three axis test.

\section{TEST CONTENT}

Loess slope failure physical model test with rainfall infiltration is the three parts of the content analysis of outdoor model monitoring, indoor physical mechanics parameter test and slope failure mechanism.

After slope model was full consolidation that was filled in outdoor, the front board of loess slope model of would been opened. Installing of water meter, the total flow was controled by water meter, the water flowing as a simulated rainfall. Turn on the tap, landslide rainfall experiment started (Fig. 3).

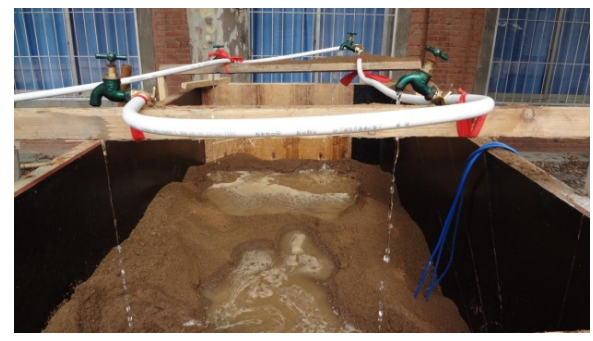

Fig. (3). Simulated Rainfall.

By controlling the duration of rainfall, the flow meter simulated different rainfall intensities. The clock time and meter dial readings were random recorded every once in a while, until the slope was failure. Due to the action of rainfall, the slope was in the final failure condition and eventually slided (Fig. 4).

At the same time of the recorded clock time and dial readings, two loess samples are gotten at the depth of $40,80 \mathrm{~cm}$. The loess physical parameters of density and moisture content were obtained at different test time. The strength parameters of different water ratio by three axial test. Each data was taken as a mathematical average of the three times test.

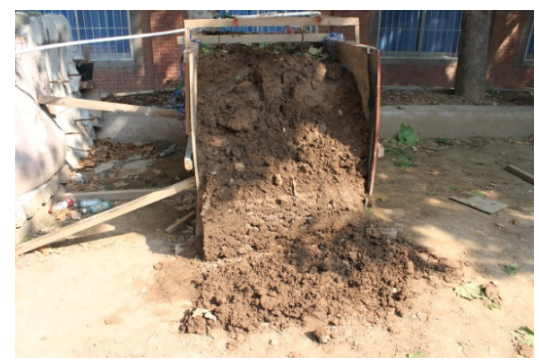

Fig. (4). Landslide. 
Table 1. The model test result data.

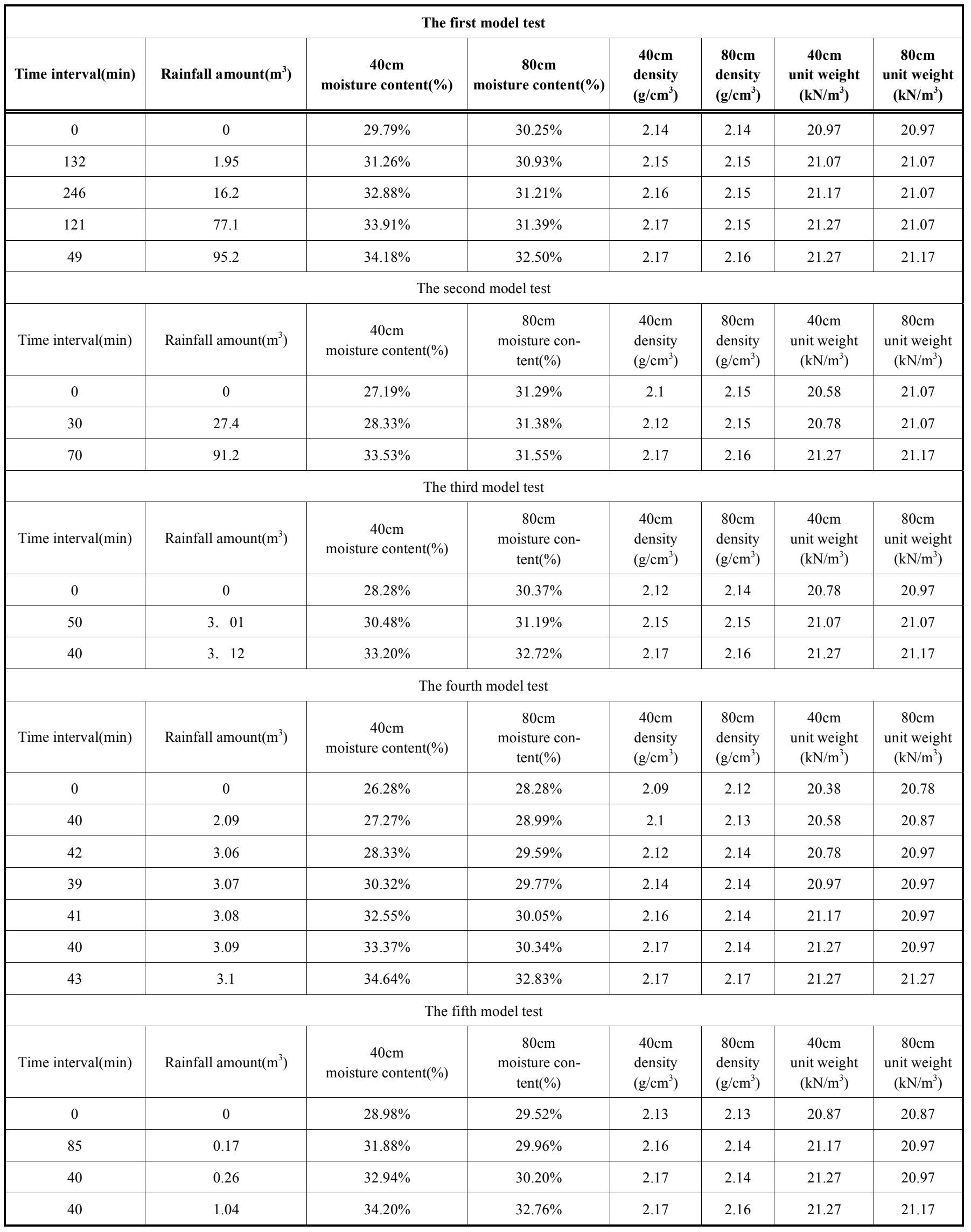


(Table 1) contd...

\begin{tabular}{|c|c|c|c|c|c|c|c|}
\hline \multicolumn{8}{|c|}{ The sixth model test } \\
\hline $\begin{array}{c}\text { Time inter- } \\
\text { val(min) }\end{array}$ & Rainfall amount $\left(\mathbf{m}^{3}\right)$ & $\begin{array}{c}40 \mathrm{~cm} \\
\text { moisture content }(\%)\end{array}$ & $\begin{array}{c}80 \mathrm{~cm} \\
\text { moisture con- } \\
\text { tent }(\%)\end{array}$ & $\begin{array}{c}40 \mathrm{~cm} \\
\text { density } \\
\left(\mathrm{g} / \mathrm{cm}^{3}\right)\end{array}$ & $\begin{array}{c}80 \mathrm{~cm} \\
\text { density } \\
\left(\mathrm{g} / \mathrm{cm}^{3}\right)\end{array}$ & $\begin{array}{c}40 \mathrm{~cm} \\
\text { unit weight } \\
\left(\mathrm{kN} / \mathrm{m}^{3}\right)\end{array}$ & $\begin{array}{c}80 \mathrm{~cm} \\
\text { unit } \\
\text { weight } \\
\left(\mathrm{kN} / \mathrm{m}^{3}\right)\end{array}$ \\
\hline 0 & 0 & $28.71 \%$ & $29.36 \%$ & 2.12 & 2.13 & 20.78 & 20.87 \\
\hline 65 & 10.55 & $33.99 \%$ & $30.40 \%$ & 2.17 & 2.14 & 21.27 & 20.97 \\
\hline 40 & 10.75 & $34.66 \%$ & $30.90 \%$ & 2.17 & 2.15 & 21.27 & 21.07 \\
\hline 40 & 11.45 & $34.83 \%$ & $31.24 \%$ & 2.17 & 2.15 & 21.27 & 21.07 \\
\hline 0 & 0 & $29.33 \%$ & $29.30 \%$ & 2.13 & 2.13 & 20.87 & 20.87 \\
\hline 30 & 14.97 & $30.40 \%$ & $30.20 \%$ & 2.14 & 2.14 & 20.97 & 20.97 \\
\hline 35 & 19.79 & $31.85 \%$ & $30.62 \%$ & 2.16 & 2.15 & 21.17 & 21.07 \\
\hline 35 & 27.2 & $32.95 \%$ & $31.06 \%$ & 2.17 & 2.15 & 21.27 & 21.07 \\
\hline 30 & 39.74 & $33.41 \%$ & $31.31 \%$ & 2.17 & 2.15 & 21.27 & 21.07 \\
\hline 45 & 44.97 & $35.20 \%$ & $33.19 \%$ & 2.18 & 2.17 & 21.36 & 21.27 \\
\hline
\end{tabular}

\section{TEST RESULTS}

Model tests were carried seven times. The test results data are shown in Table 1:

After each getting samples, the shear strength was measured by triaxial tests. Cohesion and internal friction angle was gotten with Mohr - Coulomb strength criterion. The test results data are shown in Table 2:

Table 2. Loess TriaxialTest Data.

\begin{tabular}{|c|c|c|}
\hline $\begin{array}{c}\text { Moisture } \\
\text { content } \mathbf{( \% )}\end{array}$ & Cohesion (kPa) & $\begin{array}{c}\text { Internal friction } \\
\text { angle } \mathbf{(}^{\mathbf{}} \mathbf{)}\end{array}$ \\
\hline \hline 4 & 68 & 30 \\
\hline 7 & 62 & 28 \\
\hline 10 & 60 & 27 \\
\hline 13 & 45 & 25 \\
\hline 16 & 30 & 24 \\
\hline 19 & 25 & 21 \\
\hline 21 & 20 & 20 \\
\hline 24 & 17 & 18 \\
\hline 26 & 14 & 17 \\
\hline 28 & 10 & 17 \\
\hline 30 & 8 & 15 \\
\hline
\end{tabular}

\section{LANDSLIDE MECHANISM ANALYSIS}

The process of fitting formula for experimental data used 1 stOpt software. Universal global optimization Algorithm is adopted that overcome the world in the field of optimization using iterative method must be given appropriate initial value problem. Users do not have to give initial parameters,but random given by the program. Eventually the optimal solution is found through unique global optimization.

Fitting expression between moisture and rainfall intensity, time at $40 \mathrm{~cm}$ :

$$
\begin{aligned}
& \omega_{40}=32.4725+0.4572 p^{2}+1.7256 p+ \\
& 1.1642 t^{2}+0.9775 t+1.3329 p t
\end{aligned}
$$

Fitting expression between moisture and rainfall intensity, time at $80 \mathrm{~cm}$ :

$$
\begin{aligned}
& \omega_{80}=31.0043+0.6217 p^{2}+0.4394 p+ \\
& 0.4273 t^{2}+1.0900 t+0.0625 p t
\end{aligned}
$$

Fitting expression between moisture and cohesion:

$c=0.0453 \omega^{2}-4.0510 \omega+87.7154$

Fitting expression between moisture and friction angle:

$$
\phi=-0.0002 \omega^{2}-0.5705 \omega+32.3611
$$

Fitting expression between moisture and unit weight: 


$$
\gamma=-0.0081 \omega^{2}+0.5944 \omega+10.4414
$$

Bishop slice method is adopted to seek the safety factor:

$$
F=\frac{\sum(c b+\gamma \operatorname{tg} \phi) \frac{1}{m_{\theta}}}{\sum \gamma \sin \theta}
$$

$m_{\theta}=\cos \theta+\frac{\sin \theta \cdot \operatorname{tg} \phi}{F}$

in which , $F$ is the calculation safety factor for the entire landslide of the remaind decline force; $b$ is the width of a single strip of loess $(\mathrm{m}) ; \gamma$ is stick unit weight $\left(\mathrm{kN} / \mathrm{m}^{3}\right) ; \theta$ is the angle between the bars and the horizontal sliding surface $\left(^{\circ}\right) ; c, \phi$ are the loess shear strength parameters.

Due to $c, \varphi, \gamma$ changing with depth,Hypothesis:

$$
\begin{aligned}
& c=m_{1} h+n_{1} \\
& \varphi=m_{2} h+n_{2} \\
& \gamma=m_{3} h+n_{3}
\end{aligned}
$$

The formula (1), (2) are iterated into equation (8):

$$
\begin{aligned}
& m_{1}=\left(1.7259-0.3600 p^{2}+1.3680 p+0.7709 t^{2}\right. \\
& -0.2697 t+1.2912 p \cdot t+0.0080 p^{4}-0.04617 p^{3} \\
& -0.1045 p^{2} \cdot t^{2}-0.2157 p^{2} \cdot t-0.2768 p \cdot t^{2} \\
& -0.0517 p^{3} \cdot t-0.0531 t^{4}-0.0609 t^{3}- \\
& \left.0.1382 p \cdot t^{3}\right) / 40 \\
& n_{1}=2.2106-0.0127 p^{2}-3.2817 p-2.0187 t^{2} \\
& -0.8144 t-2.6166 p \cdot t+0.0015 p^{4}+0.1182 p^{3} \\
& +0.2322 p^{2} \cdot t^{2}+0.4646 p^{2} \cdot t+0.5768 p \cdot t^{2} \\
& +0.1069 p^{3} t+0.1145 t^{4}+0.1640 t^{3}+0.2788 p t^{3}
\end{aligned}
$$

The formula (1), (2) are iterated into equation (9):

$$
\begin{aligned}
& m_{2}=\left(0.8562-0.0953 p^{2}-0.2344 p-0.0649 t\right. \\
& +0.4302 t^{2}+0.7417 p \cdot t+0.0002 p^{3}+0.0005 p^{2} t^{2} \\
& +0.0010 p^{2} \cdot t+0.0012 p \cdot t^{2}+0.0003 t^{3} \\
& \left.+0.0002 p^{3} \cdot t+0.0003 t^{4}+0.0006 p \cdot t^{3}\right) / 40 \\
& n_{2}=12.7684-0.1720 p^{2}+0.2107 p-1.1097 t^{2} \\
& -0.5055 t-1.5201 p \cdot t-0.0005 p^{3}-0.0011 p^{2} t^{2} \\
& -0.0021 p^{2} \cdot t-0.0025 p \cdot t^{2}-0.0004 p^{3} \cdot t \\
& -0.0012 p \cdot t^{3}-0.0003 t^{3}-0.0006 t^{4}
\end{aligned}
$$

$$
\begin{aligned}
& m_{3}=\left(-0.1178+0.0430 p^{2}-0.0774 p-0.0420 t^{2}\right. \\
& +0.0336 t-0.0658 p \cdot t-0.0014 p^{4}+0.0084 p^{3} \\
& +0.0187 p^{2} \cdot t^{2}+0.0094 p^{3} \cdot t+0.0496 t^{2} \\
& +0.0386 p^{2} t+0.0059 t^{4}+0.0247 p \cdot t^{3} \\
& \left.+0.0109 t^{3}\right) / 40
\end{aligned}
$$

$$
\begin{aligned}
& n_{3}=21.3197-0.0358 p^{2}+0.1953 p+0.1138 t^{2} \\
& +0.0332 t+0.1296 p \cdot t-0.0003 p^{4}-0.0212 p^{3} \\
& -0.0417 p^{2} \cdot t^{2}-0.0194 p^{3} t-0.0831 p^{2} \cdot t \\
& -0.1033 p \cdot t^{2}-0.0169 t^{4}-0.0498 p t^{3}-0.0293 t^{3}
\end{aligned}
$$

So, the formula (6) changes:

$$
F=\frac{\sum\left[\left(m_{1} \cdot h+n_{1}\right) b+\left(m_{3} \cdot h+n_{3}\right) \operatorname{tg}\left(m_{2} \cdot h+n_{2}\right)\right] \frac{1}{m_{\theta}}}{\sum\left(m_{3} \cdot h+n_{3}\right) \sin \theta}
$$

When $F>1$, loess slope is stability. When $F=1$, loess slope is in limit equilibrium. When $F<1$, loess slope is damaged.

\section{CONCLUSION}

Through field model testand laboratory test, the relational expression was got between landslide safety factor and rainfall intensity, rainfall duration, moisture content being an intermediate variable. The relationship was studyed of between loess landslide and rainfall. The expression need to be tested in the project and be verified with the theoretical calculation method in the future.

\section{CONFLICT OF INTEREST}

The authors confirm that this article content has no conflict of interest.

\section{ACKNOWLEDGEMENTS}

This work is supported by the National Natural Science Foundation of China (No. 51478383).

\section{REFERENCES}

[1] H. Wang, and M. Wang, "Experimental investigation on rainfall infiltration and solute transport in layered porous and fractured media," J. Coal Sci. Eng., vol. 18, pp. 29-34, 2012.

[2] S. Marcus, and S. Jürgen, "Parameterization of the EROSION 2D/3D soil erosion model using a small-scale rainfall simulator and upstream runoff simulation," Catena, vol. 91, pp. 47-55, 2012.

[3] R. V. Kale, and B. Sahoo, "Green-Ampt Infiltration Models for Varied Field Conditions: A Revisit,"Water Resour. Manage., vol. 25, pp. 3505-3536, 2011.

[4] V. U Joshi, and D. T Tambe, "Estimation of infiltration rate, runoff and sediment yield under simulated rainfall experiments in upper Pravara Basin, India: Effect of slope angle and grass-cover," $J$ Earth Syst. Sci., vol. 119, pp. 763-773, 2010.

[5] X.B. Tu, A.K.L. Kwong, F.C. Dai, L.G. Tham, and H. Min, "Field monitoring of rainfall infiltration in a loess slope and analysis of failure mechanism of rainfall-induced landslides," Eng. Geol., vol. 105, pp. 134-150,2009.

[6] H. Kato, Y. Onda, Y. Tanaka, and M. Asano, "Field measurement of infiltration rate using an oscillating nozzle rainfall simulator in the cold, semiarid grassland of Mongolia," Catena, vol. 76, pp. $173-181,2009$

[7] J. Li, B. Zeng, Y. Wang, and L. Shen, "Physical simulation of urban rainfall infiltration," J. China Univ. Mining Technol., vol. 18, pp. 0293-0259, 2008.

[8] H. Meng, T.R. Green, J.D. Salas, and L.R. Ahuja, "Development and testing of a terrain-based hydrologic model for spatial Hortonian Infiltration and Runoff/On," Environment. Model. Software, vol. 23, pp. 794-812, 2008.

[9] M. Lee, A. Kassim, and N. Gofar, "Performances of two instrumented laboratory models for the study of rainfall infiltration into unsaturated soils," Eng. Geol., vol. 117, pp. 78-89, 2011. 
[10] Z. Liao, Y. Hong, J. Wang, et al., "Prototyping an experimental early warning system for rainfall-induced landslides in Indonesia using satellite remote sensing and geospatial datasets," Landslides, vol. 7, pp. 317-324, 2010.

[11] Aurelian C. Trandafir, Roy C. Sidle, Takashi Gomi, T.Kamai, "Monitored and simulated variations in matric suction during rainfall in a residual soil slope," Environ. Geol., vol. 55, pp. 951-961, 2008.

[12] Z. Zhang, C. Peng, and Z. Yan, "Effects of rain infiltration on fissured slope stability," Electron. J. Geotech. Eng., vol. 19, pp. 2159-2164, 2014

[13] Jiang Zhong-Ming, Zeng Ling, Fu Hong-Yuan and He ZhongMing," Seepage characteristics of thick coating slope in raining condition," J. Central South Univ. (Science and Technology), vol. 43, pp. 2782-2788, July 2012.

[14] K. Suzuki, "Groundwater flow after heavy rain in landslide-slope area from 2-D inversion of resistivity monitoring data," Geophysics, vol. 78, pp. 733-743, 2013.

[15] C.Z. Gu, X.W. Hu, M.C. Zhang, Z. Yao, and H.Y. Hu, "Analysis of flow motion and its effect on the slope stability of plane sliding landslide saturated under heavy-rain-A case study of Ermanshan landslide in Hanyuan county of Sichuan province," Rock Soil Mechanics, vol. 34, pp. 1075-1081, 2013.

[16] J.L. Wang, J.F. Zhang, S.L. Li, and H.D. Cui, "Numerical analysis of infiltration of atomized rain into plunge pool slope in Wudongde hydropower project," Rock Soil Mechanics., vol. 33, no. 9, pp. 2845-2849+2856, 2012.

(C) Jiaming Han; Licensee Bentham Open.

This is an open access article licensed under the terms of the (https://creativecommons.org/licenses/by/4.0/legalcode), which permits unrestricted, noncommercial use, distribution and reproduction in any medium, provided the work is properly cited. 